\title{
Om forkyndelse og samfund under enevældens sidste 100 år - herunder: Grundtvig og menneskerettighederne
}

\author{
Af Jens Rasmussen
}

Michael Bregnsbo: Samfundsorden og statsmagt set fra pradikestolen. Danske prasters deltagelse $i$ den offentlige opinionsdannelse vedrørende samfundsordenen og statsmagten 1750-1848, belyst ved trykte proedikener. En politisk-idéhistorisk undersøgelse, 1997, 464 sider, ill.

Der er her tale om en omfattende undersøgelse ud fra den opfattelse, at prædikenerne var datidens massemedier: påvirkningskanaler overfor befolkningen. Dog understreges det, at »det ikke var så mange, der gik i kirke så tit« (s. 97), og af de, som så kom, var flere - »af forskellige grunde« (s. 90ff.) - ikke altid i stand til at opfatte budskabet. Af gode grunde har forfatteren ikke kunnet måle modtageligheden, men har til gengæld gjort sig overvejelser om gudstjenestedeltagelsen $\mathrm{i}$ det indledende kapitel, og den fandt et nyt lavere niveau med oplysningstidens og romantikkens periode, og det $\mathrm{i}$ takt med den manglende anvendelse af Danske Lovs kirketugtsbestemmelser og helligdagslovgivning, som var ude af pagt med tidens ånd. Med Helligdagsforordningen i 1845 blev kirkegangstvangen således ophævet. Selv om der er megen usikkerhed om, hvor mange der har hørt prædikenerne og om tilhørernes modtagelighed, så viser prædikenerne under alle omstændigheder, "hvorledes præsterne ude i landet og i København har stillet sig til diverse samfundsspørgsmål« (s. 97).

Formålet med Michael Bregnsbos ph.d.-afhandling er for perioden 1750-1848 »at undersøge danske præsters deltagelse i den offentlige opinionsdannelse vedr. samfundsordenen og statsmagt«. Forfatteren har fundet frem til ikke mindre end 1431 »biografiske enheder«, som spænder lige fra udgivne enkeltprædikener og hele prædikensamlinger - endda i »op til 12 svære bind « (s. 17). Materialet behandles statistisk i det indledende kapitel om kildematerialet. Kun mellem 8 og 19 pct af prædikenerne indeholder relevante oplysninger som drejer sig om afhandlingens problemstilling, og kun mellem 15 og 30 pct af de ialt 536 præster har udgivet prædikener, hvor disse oplysninger er fundet. Således fremgår det, at der er langt mellem udsagn om samfundsorden og statsmagt i disse prædikener, og - man må næsten gå ud fra - at de præster som går længst tilhører oplysningstidens og rationalismens åndsretninger, der $\mathrm{i}$ høj grad ud fra et optimistisk menneskesyn og fornuftens primat interesserede sig for samfundets forbedring og oplysning af det enkelte menneske.

I øvrigt understreger M. Bregnsbo, at det ligger »uden for denne undersøgelses rammer nærmere at spore ophavet til de idéer, som prædikanterne giver udtryk for « (s. 329). I forbindelse med de mange prædikencitater gives heller ingen henvisning til den bibelske prædikentekst; dog omtaler forfatteren gerne udsagnenes sammenhæng med den øvrige prædiken. 
Af prædikenerne fremgår det, at der allerede et par årtier efter 1750 blev lagt vægt på folkesuveræniteten i forståelsen af den enevældige statsmagt. Kongens magt var overdraget ham af folket. Det teokratiske udgangspunkt - at kongen direkte var indsat af Gud - gled i baggrunden. Opfattelsen af kongen som indsat i sin magt og vælde af Gud var således blevet forladt til fordel for en ny naturretsligt baseret statsopfattelse. Kongen og ovrigheden skulle regere til gavn for folket. Denne ny dynamiske enevælde og ny samfundsorden tog form af en landsfaderlig oplyst enevælde, der som en særlig »dansk vej« - uafhængig af Den franske Revolutions voldsomhed i 1789 - efterhånden blev kendetegnet af frihed, lighed og menneskerettigheder.

Udtrykket »Menneske-Rettigheder« dukkede op omkring 1760 formentlig med den tyskfødte hof præst J.A. Cramer (s. 170), men nævnes kan flere i den generation som oplevede Den franske Revolutions tid, selv om de i andre sammenhænge henviste til Den lutherske Hustavles orden: J.C. Schønheyder, P.C. Cramer og H.G. Clausen. Ikke mindst for sidstnævnte var kristendom og menneskerettigheder to sider af samme sag (s. 179, 184).

Den gamle patriarkalske orden - Den lutherske Hustavles verden - er beskrevet af $M$. Bregnsbo. Hustavlens verdens tre stænder bestod af øvrighedsstand (øvrighed og undersåtter), lærestand (kirkestand: præster og menigheder) og husstand (husbond og tjenestefolk), hvor hvert samfundsmedlem enten var foresat eller underordnet $i$ indbyrdes handlingsrelationer, $i$ hvilke kristenlivet skulle leves. Hustavlen var en del af katekismeundervisningen, og den var tilføjet Luthers lille Katekismus (s. 105f.).

En opremsning af Hustavlens orden kan iagttages hos f. eks. pastor Johan E. Heilmann, Lunde ved Svendborg, der i en ligprædiken 1774 over en husmand med familie, som i sin ulykke havde druknet sig, udtrykte, at mange havde svigtet dem: „Saa kommer da med mig til hiin Grav! Forældre! - Huusfædre! - Madmødre! - Lærere! - Øvrigheder! - Dommere! - Alle I, til hvis Opsigt, Underviisning, Anførsel, Optugtelse, og Forsvar de Unge ere anbetroede - Seer! - O! hvilket bebreidende Exempel for Eder alle« (s. 111).

Denne Hustavles orden blev nævnt i prædikener omkring 1750 som alment bekendt, men efterhånden blev denne patriarkalske opfattelse udvandet. Godsejerne og dermed adelsmændene var under stigende kritik, og udspillede dermed snart deres husbond-rolle, og de blev afløst af statens orden og omsorg, hvor det nu blev embedsmændene som skulle opretholde samfundsordenen. Pastor L.N. Fallesen, Vor Frue kirke, København, udtrykte i en prædiken i 1802 (s. 261), at embedsmændene var her i alle »Landets Stæder og Provindser ... Fyrsternes Mund og Haand«, dem der sørgede for at føre fyrstens befalinger ud i livet til gavn for undersåtterne.

Statens rygrad blev nu middelstanden, som dels bestod af byens næringsdrivende borgere, dels af den med landbrugsreformerne efterhånden opvurderede gårdmandsklasse og dels af de ledende: embedsmændene. Prædikenerne viser også, at denne udvikling kun omfattede enkelte samfundsgrupper. For det må tilføjes, at kvinder og tyende - socialt set - fortsat befandt sig i Hustavlens verden. Kun gårdmænd havde gjort sig fri og fået rettigheder.

Om denne ny middelstand taltes der indtrængende i stiftsprovst H.G. Clausens prædiken fra 1813 i Vor Frue kirke, København. Han talte til københavnerborgeren: „Dets (dvs. borger- 
samfundets) Anliggender ere ogsaa dine; dets Held er dit, ligesom dets Uheld. I dig selv elsker du dit Fædreland; med dets Fordeel seer du din egen i uadskillelig Forbindelse« (s. 162).

Det er M. Bregnsbos overbevisning, at »selv om præsterne geografisk var isoleret og spredt over det ganske land, synes de dog generelt at have fulgt med de ledende strømninger og været i pagt med tiden« (s. 327). Den nye samfundsorden havde gjort folkets tarv til formålet for statens virksomhed, og derfor lå den tanke nær, at folket selv ville bestemme. Således ser man efter 1830, at flere præster anså enevælden for udlevet. De var grebet af liberale ideer, og gjorde det klart i deres prædikener, at forandringer i styreform uafvendeligt måtte komme som følge af udviklingen.

Denne tankegang mærkes for eksempel hos den rationalistiske pastor Carl H. Visbys prædiken i 1838 (Vor Frelsers kirke, Christianshavn), hvor han omtaler folket, hvis »Nationalcharacteer og medfødte Livlighed engang drev det (dvs. folket) saa langt ud over Grændserne for det Rette og Sømmelige, har ogsaa, veiledet ved sine egne dyrekjøbte Erfaringer, siden viist, at det forstaar at benytte en fornuftig Frihed paa en besindig og rolig Maade, og derved atter efterladt Verden et lærerigt Exempel«. Således behøvede den daværende styreform ikke at bestå til evig tid - for folket kunne forvalte »en fornuftig Frihed« (s. 290f.).

Her gøres især brug af historikeren Hans Jensens historisk-politiske udviklingstanke startende med landbrugsreformerne, skoleloven, og oprettelsen af stænderforsamlingerne (valgret og valgbarhed), og sluttende med systemskiftet i 1848. Godt nok var der i 1848-49 med Grundloven tale om et formelt brud med Kongeloven (1665), men det foregik fredeligt og som en glidende overgang - netop langt fra Den franske Revolutions tanker.

M. Bregnsbos her skitserede analyse af præsters offentlig, trykte prædikener viser anvendelsen af et kendt kildemateriale på en ny måde. Dette kildemateriale er på fornem vis til slut $i$ afhandlingen gengivet i en »Bibliografi over Prædikener 1750-1848«, ligesom der er givet en beskrivelse af »Præstelevnedsløb«, samt en »Liste over gennemsete Tidsskrifter «. Altsammen er det værdifuldt for den, som vil arbejde videre. Bregnsbo har klart påvist, at dette materiale støtter og udvider forståelsen af forudsætningerne og af selve overgangen fra enevælde til repræsentativt styre i 1848, sådan som udviklingen forløb de sidste 100 år inden enevældens afslutning i perioden 1750-1848 - ikke mindst ud fra Hans Jensens udviklingstanke, der indebærer en ide om »en almen uafvendelig Udvikling, baaret af Nødvendighed og derfor ogsaa bestemmende for de Foranstaltninger, der fra Tid til anden maatte blive krævet og gennemført« (s. 288).

Forfatteren har i denne undersøgelse helt villet se bort fra åndshistoriske og teologiske forudsætninger for prædikenernes udsagn om samfundsorden og statsmagt. I afhandlingens indledning findes et afsnit om "Tidens prædikenkunst og åndsretninger «, der dog mere beskæftiger sig med prædikenkunst end med åndsretninger. Selv om M. Bregnsbo med megen omtanke ikke vil vedkende sig et teologisk eller et åndshistorisk udgangspunkt for sine prædikenanalyser, så kalder han dog sin afhandling for »en politisk-idéhistorisk undersøgelse«. Derfor savnes netop en nærmere idéhistorisk beskrivelse, dels af filosoffen J.G. Fichtes tanker om middelstandens - og dermed akademikernes og embedsmændenes - ledende betydning i samfundet, og dels af filosoffen E. Kants opstillede morallære, som blandt andet for de rationalistiske præster havde en vis betydning, og derfor kunne have været relevant for en bedøm- 
melse af prædikeners udsagn om samfund og statsmagt - således pligtbudet over for almenvældet (staten) hos enhver borger. Begge de her nævnte filosoffer fik betydning for det kuld af akademikere, som blev uddannet i 1790'erne, og som var den kerne af embedsmænd, som et slægtled senere dominerede kongens statsapparat (A.S. Ørsted, J. Collin, J.P. Mynster m.fl.)

Afhandlingens beskrivelse af de mange samfundsrelevante udsagn, især fra rationalistiske præster, kan samtidig bruges til at bekræfte tidens markante kirkelige skel. Selvom Bregnsbo ikke indlader sig herpå, kan man næsten ikke lade være med de åndshistoriske og teologiske reflektioner. For især to ledende personligheder, pastor N.F.S. Grundtvig og biskop J.P. Mynster, gjorde teologisk og kirkeligt op med rationalismen. Dette opgør fik netop betydning for deres kritiske holdning til rationalistiske præsters samfundsrelevante holdning i prædikenerne - og flere præster var enige med dem.

Michael Bregnsbo skildrer således meget rammende Grundtvigs opgør med menneskerettighederne, og han mener, at Grundtvigs isynspunkter ikke var typiske for den danske præstestand på dette tidspunkt« (s.193). Menneskerettighederne var ifølge Grundtvig udtryk for en menneskelig selvforherligelse, og dermed i modstrid med kristendommen - således sagt i en prædiken fra Frederikskirken i 1833, citeret af Bregnsbo:

»det gruelige Vilde-Rede, hvori aandløs Selv-Klogskab har indviklet os, da den forgudede sig selv, og vilde indbilde os, var Guder allerede, naar vi blot aflukkede os forsvarlig fra den Gud i hvem vi leve og røres og ere og paastod kiækt, det hørde til vore ufortabelige Menneske-Rettigheder at raade os selv, saliggiøre os selv, uden at Gud enten kunde eller maatte blande sig deri, da vi ellers erklærede ham for en Despot og Tyran, der blot vilde have Slaver og blinde Redskaber, ikke frie, selvstændige Borgere i sit Rige« (s. 189; jf. N.F.S. Grundtvigs prædikener, udg. Chr. Thodberg, 1984, bd. VI, s. 228).

Grundtvig mente, at frihed, lighed og broderskab var »topmaalt Daarskab«. Det første mængden således ville gøre, hvis den fik såkaldt frihed, var at nedbryde alle rettigheder under påskud af, at de stod i vejen for ligheden - og dermed kom kun de værste og de frækkeste til at råde. Den lighed, de ville prøve at indføre, ville »for deres egen Fordeels og Roligheds Skyld (være), at alle Andre skal være ligesaa slette som de, men aldrig tænke paa at blive ligesaa rige og mægtige og skiøndt de Christne godt kan tjene dem i det Sidste, kan de det dog umuelig i det Første, hvorfor ogsaa Erfaring lærer at de Christne aldrig blev bittrere hadede og forfulgde, og nægtede alle Menneske-Rettigheder, end hvor Verden arbeidede ret paa sin Frihed og Lighed «. Under de forhold ville broderskab ikke blive til noget (s. 191; jf. N.F.S. Grundtvigs prædikener, udg. Chr. Thodberg, 1984, bd. VIII, s. 168).

Lighed for loven var Grundtvig dog tilhænger af, men retten var noget af det første, der blev trådt ned, når verden prøvede at indføre frihed. Når således den af Gud givne øvrighed var magtesløs og afvæbnet og ondskaben havde fået frit spil på grund af friheden, blev også broderskabet ødelagt.

Menneskerettighederne var for Grundtvig udtryk for en tøjlesløs frihed, som hidrørte fra oplysningstidens og revolutionstidens tænkning, og hvor selvrådigheden ville afvæbne den af Gud indsatte øvrighed. Derfor mente han, at kristne burde glæde sig over borgerlig frihed inden 
for rammerne af et velordnet samfund, der var et gode, og som sikrede f.eks. skrivefrihed og religionsfrihed, der tog hensyn til den enkeltes samvittighed; grundlæggende gik Grundtvig ind for næringsfrihed, fæstebøndernes ejendomsret, skolefrihed og samvittighedsfrihed, og han fandt, at ligheden altid burde vige for friheden. I afhandlingen nævnes Grundtvigs frihedsbegreb, der ikke var udsprunget af Den franske Revolution, men var inspireret fra England ikke mindst $i$ kraft af hans Englandsrejser 1829-31. Frihed var efter Grundtvigs mening »altid i forbund med ånd og menneskelighed; den franske (revolutions) frihed var dyrisk og selvrådig, pøbelens og rovdyrenes frihed, men den engelske er for ansvarlige mennesker" (s. 193). Den ægte menneskelige frihed - i modsætning til den tøjlesløse - styrkede de gode og svækkede de onde.

Grundtvig støttede den lutherske øvrighedsopfattelse, to regiment-læren. De to regimenter virkede henholdsvis ved åndelige midler og ved den verdslige øvrigheds håndhævelse, $0 \mathrm{~g}$. Bregnsbo fremhæver, at lærestanden og øvrighedsstanden inden for Hustavlens orden svarer til disse to regimenter (s. 202ff.).

Menneskerettighederne havde dog fortalere og modstandere blandt præsterne i 1830'erne. Pastor C.H. Visby, Vor Frelsers kirke, Christianshavn var tilhænger: »Hvor nedværdigende Menneskesalg og Slaveri forekommer os, har der dog været den Tid, da man studsede ved at høre denne Yttring udtalt. Hvor naturligt og ligefrem det forekommer os, at Fødsel allene ikke kan give noget Menneske Fortrin for Andre og Adelsstolthed er Daarskab, har der dog været Aarhundreder, da Ingen dømte saaledes. Hvad der er simpel og indlysende Sandhed for os, har ikke paa een Gang eller uden Møie banet sig Vei til denne Anerkjendelse» (s. 194).

Blandt modstandere omtaler Bregnsbo pastor E. Mau i Hårslev på Sydvestsjælland. Han var tilknyttet vækkelsen og var tilhænger af den patriarkalske opfattelse. Særlig mente han, at "Krævementalitet« og misfornøjelig pukken på egne rettigheder havde udartet sig hos tilhængere af menneskerettighederne, og han var meget tvivlende over for, om disse tilhængere var kristne.

M. Bregnsbo konkluderer på grund af Grundtvigs stærke reaktion imod menneskerettighederne, "at disse må have haft en ikke ubetydelig udbredelse på det tidspunkt. Ellers ville han vel næppe have følt sig foranlediget til at tage så skarpt afstand fra dem». Grundtvigs frihedstanker medførte ikke den konsekvens, at han gik ind for en demokratisk forfatning. Han frygtede for, at demokrati kunne udvikle sig til massetyrani. Således var han tilhænger af oplyst enevælde.

Det er interessant, når Brengsbo mener, at mange præster tænkte positivt om menneskerettighederne på denne tid (s. 193). Det drejede sig formentlig om præster af den oplysningsprægede og den rationalistiske retning, som ifølge den sjællandske biskop J.P. Mynsters visitatsbog stadig var dominerende frem til 1840. Denne rationalistiske og "moderne« linie blev ikke mindst varetaget af familien Clausen (stiftsprovst H.G. Clausen, svigersønnen pastor P.C. Stenersen Gad og sønnen, den liberale politiket og prof., dr. theol. H.N. Clausen) - men flere liberale var af samme grundholdning.

Alligevel må det siges, at billedet ændrede sig i løbet af 1830'erne og 1840'erne. Grundtvigs linie blev i det mindste fulgt af vækkelsespræsterne på Fyn og Sjælland, og de stod i skarpeste modsætning til den liberale prof. Clausen og universitetsteologien. Ligeledes fremkom 
en anden type præster, som kan kaldes for centrumkirkelige, og som ville en rummelig evangelisk-luthersk statskirke for alle med staten som beskytter og værner af evangeliskluthesk tro, og som nærmest havde biskop Mynster som sit udgangspunkt; de havde også distance til universitetsteologien og de nye politiske liberale strømninger.

Disse overvejelser omkring M. Bregnsbos afhandling ændrer slet ikke ved, at vi her har en afhandling som er helstøbt, og som også giver en generel indføring $\mathrm{i}$ den danske enevoldstids politiske opfattelser i perioden 1750-1848. Problemstillingen følges konsekvent, hvilket betyder, at centrum ligger i præsternes offentligt udtrykte politisk-idéhistoriske udsagn, som har almen karakter, og som behandles suverænt, men som ikke på mere indgående måde sættes ind $\mathrm{i}$ et åndshistorisk perspektiv, hvilket nok ville have været berigende. Bogen kan varmt anbefales. 